\title{
The Use of AHP (Analytical Hierarchy Process) as Multi Criteria Decision Tool for the Selection of Best Water Supply Source for Benin City
}

\author{
Ihimekpen, N. ${ }^{1}{ }^{1 *}$ and Isagba, E.S. ${ }^{1}$ \\ ${ }^{1}$ Department of Civil Engineering, University of Benin, Benin City, Nigeria \\ Corresponding Author: *ebuwa.isagba@uniben.edu
}

\begin{abstract}
This paper analysis the potential of using Analytical hierarchy process (AHP) as an analytical tool in multi criteria decision analysis, to identify the best water supply source for Benin City. The water supply sources available in Benin are Rainfall, Ground Water, Surface Water and Storm Water Runoff. In order to compare characteristics and rank the four major water supply source, expert advice was solicited, structured questionnaires administered, and a set of criterions was derived that would be used in evaluation procedure. The following set of criterions was adopted: Cost, Availability, Ease of distribution, Accessibility, Sustainability, Quality. In analysing the pairwise comparative judgments in this study, Ground Water was the most important alternative as it had the highest score of 0.4130 in the computation of the weighted average, making Ground Water the best water supply source for Benin City.
\end{abstract}

Keywords: Criteria, Alternatives, Water Supply Sources, AHP, Multi Criteria

\subsection{Introduction}

Water is an essential life sustaining element. It pervades our lives and is deeply embedded in our cultural background (United Nations, 2006). The importance of water to human existence has been widely covered in literature even though it still invokes inquiries for research. The use of water cut across almost all segments of human endeavours and it is deeply imbedded in our cultural and religious background (United Nations, 2006). Selecting the best water supply source for an urban area may be understood as ultimate decision-making after systematic evaluation of appropriate alternatives is performed and related decision space is created.

The selection of the right water supply source requires rigorous analysis to evaluate all the alternatives and extant conditions of the location for which water supply is required. The criteria for the determination of the source of water are usually numerous, with each having its pros and cons. Some of these criteria include power supply, water demands, population, cost of development, accessibility, treatment requirements, and quantity of the water in reserve; pollution propensity and the ease of distribution. The use of the manual approach for the selection of suitable water supply source using the various criteria is excessively time consuming and usually lends itself to lots of assumption, resulting in over design or under designed of the water supply systems. Multi criteria analysis helps in the processes of selecting the most suitable water source while considering the various peculiarities of a location.

The Analytic Hierarchy Process (AHP) (Saaty, 1980, 1986, 1996, 2005) appears to be a flexible decision making tool for multiple-criterion problems such as selection of the best water supply source. It enables decomposition of a problem into hierarchy and assures that both qualitative and quantitative aspects of a problem are incorporated in evaluation process. AHP has been successfully applied in case studies in water resource Engineering.

This paper intends to establish using AHP a multi criteria analysis tool to select the best water supply source for Benin City. It also examines the various alternatives available to residents and 
determines the best choice having established suitable criteria to ensure sustainability of the selected choice of water supply for residents of the study location.

\subsection{Material and Methods}

\subsection{Description of Study Area}

Benin City, the capital of Edo state, is located in the south-south part of Nigeria. Figure 1 shows the map of Benin City with distribution of buildings, roads and other major infrastructures indicated.

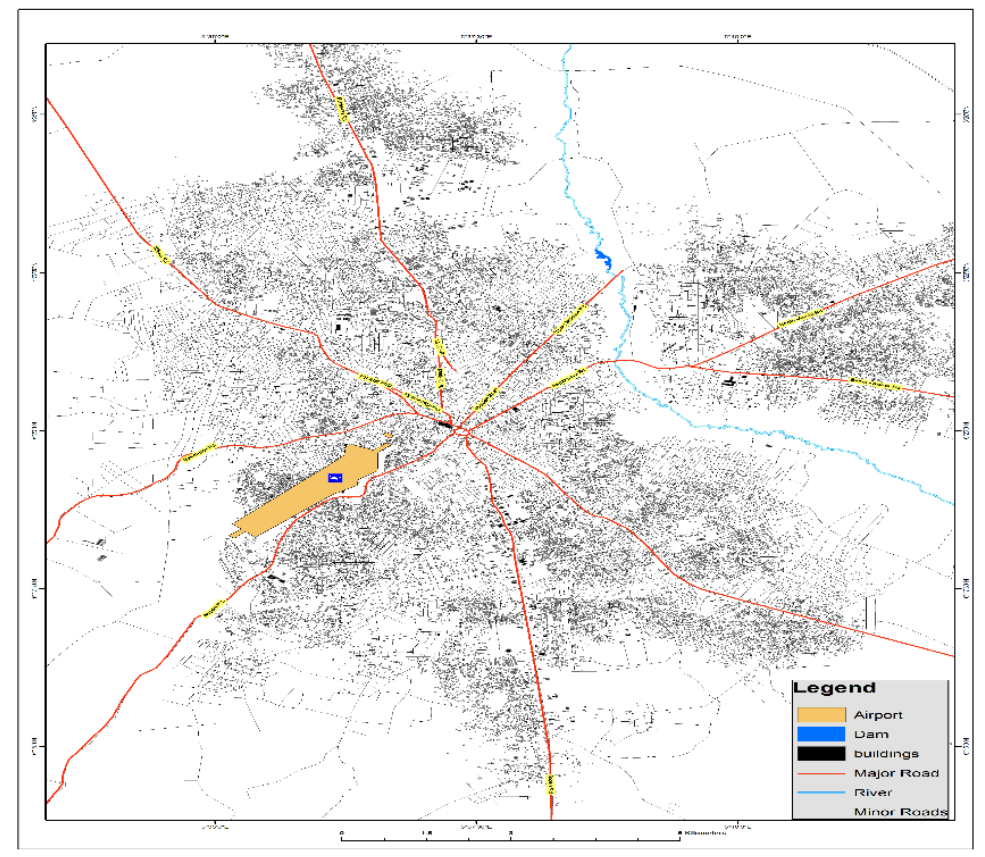

Figure 1: Map of Benin City

There are four major water supply source in Benin City, these include:

i. Rainfall water: This forms a good percentage of water supply source in Benin City, especially during the rainy seasons. The water is mostly collected by rainfall harvesting from roof catchment.

ii. Surface water runoff: Benin City being in the southern part of Nigeria and close to coastal areas, have a good proportion of rivers and streams. Surface water was the main source of water supply in the 80's until the exploration of ground water and emergence of sunk boreholes.

iii. Ground water: Benin City has an abundance of ground water which is being explored in recent times in the form of sunk boreholes.

iv. Storm water runoff: As a result of heavy rains experience yearly, Benin City has a good proportion of storm water runoff into reservoirs which can be used as water supply source.

\subsection{Methodology}

To determine best water supply source in ranks, expert advice was solicited and a set of criteria was derived that would be used in evaluation procedure. The following set of criteria was adopted: Cost, Availability, Ease of distribution, Accessibility, Sustainability, Quality. AHP method was used in determining the weights for the selected criteria which was used to determine the best water supply source for the study area.

A pair wise comparison was carried out. This is achieved by comparing each criterion with the other criteria i.e. how is criterion A more important than criterion B using values from 1 to 9 see Table 1. Based on Satty's theory, a Pair-wise Comparison Matrix (weighing) is constructed: according to 
Kasperczyk \& Knickel (2006) and Ariff et al., (2008). Weighting coefficients for all alternatives were derived by AHP with respect to the goal which is 'Evaluating the best water supply source'. Weighing coefficients for all criterions with respect to the goal are derived using the Satty's scale after a decision has been reached on the importance of an alternative over another alternative based on expert knowledge. The pairwise comparison used the Saaty's scale of pairwise comparisons (Render and Stair, 2000).

Table 1: Satty's 9-Point Scale (Source: Alireza 2014)

\begin{tabular}{cll}
\hline Importance & Definition & Explanation \\
\hline 1 & Equal importance & Two elements have equal importance regarding the element in higher level \\
3 & Weak dominance & Experience or judgement slightly favours one element \\
5 & Strong dominance & Experience or judgement strongly favours one element \\
7 & Demonstrated dominance & Dominance of one element proved in practise \\
9 & Absolute dominance & The highest order dominance of one element over another \\
$2,4,6,8$ & Intermediate values & Compromise is needed \\
\hline
\end{tabular}

The procedure used for the AHP analysis was the basic AHP procedure comprising of the following steps (Moore \& Weatherford, 2001);

Step 1: Developing the weights of the criteria by:

i. Developing a single pair wise comparison matrix for the criteria;

ii. Multiplying the values in each row together and calculating the nth root of the product;

iii. Normalizing the aforementioned nth root of products to get the appropriate weight;

iv. Calculating and checking the consistency Ratio (CR)

Step 2: Developing the rating for each decision alternative for each criterion by:

i. Developing a pair wise comparison matrix for each criterion, with each matrix containing the pair-wise comparisons of the performance of decision alternative on each criterion;

ii. Multiplying the values in each row together and calculate the nth root of the product;

iii. Normalizing the aforementioned nth root of the product values to get the corresponding ratings;

iv. Calculating and checking the Consistency Ratio (CR).

In real life decision problems, pairwise comparison matrices are rarely consistent. But decision makers would like to reach in the level of the consistency of the judgments, because inconsistent judgments may lead to meaningless decisions (Bozóki et. al. 2007). Saaty (1980) proposed the formula for calculating inconsistency: The equation is given as;

$$
\mathbf{C I}_{\mathbf{n}}=\frac{\lambda_{\max }-\mathbf{n}}{\mathbf{n}-\mathbf{1}}
$$

Where:

$\mathrm{CI}_{\mathrm{n}}$ Is Consistency Index,

$\lambda_{\max }$ Is the Eigenvalue and $\lambda_{\max }>n$, and

$n$ is the number of comparisons

Next, $\lambda_{\max }$ was calculated using equation (2):

$$
\boldsymbol{A} \boldsymbol{x}=\lambda_{\max } x
$$

Where: 
A is the comparison matrix of size $n \times n$, for $n$ criteria, and

$\mathrm{X}$ is the Eigenvector of size $n \times 1$.

$$
C R_{n}=\frac{C I_{n}}{R I_{n}}
$$

$C R_{n}$ is Consistency Ratio which Saaty (1980) concluded that if the value of Consistency Ratio is smaller or equal to $10 \%$, the inconsistency is acceptable. If the Consistency Ratio is greater than $10 \%$, we need to revise the subjective judgment, and $R I_{n}$ is a Random Consistency Index, in which $n$ is the number of comparisons.

The Random Index Table for values of $\mathrm{n}$ is presented in Table 2 .

Table 2: Random Index Table (Source: Satty 1980)

\begin{tabular}{cc}
\hline $\mathbf{n}$ & Random Index (RI) \\
\hline 1 & 0.00 \\
2 & 0.00 \\
3 & 0.58 \\
4 & 0.90 \\
5 & 1.12 \\
6 & 1.24 \\
7 & 1.32 \\
8 & 1.41 \\
9 & 1.45 \\
\hline
\end{tabular}

Step 3: Calculate the weighted average rating for each decision alternative so as to choose the one with the highest score.

\subsection{Results and Discussion}

Results obtained from expert survey and multi criteria analysis are presented below

\subsection{AHP Analysis}

Adopting the procedure and formula discussed in section two, using the information from water experts, we obtained our pairwise comparison matrix represented in Tables $3-11$ for the criterions and alternatives and further calculated our consistency ratio (CR) and consistency index (CI).

The algorithm for the results presented in Tables $3-10$ is as follows:

$\lambda \max =\Sigma\left(\mathrm{SUM}^{*} \mathrm{PV}\right)=1.0472+1.0551+1.2032+0.9172+1.1335+0.9709=\mathbf{6 . 3 2 7 1}$

Consistency Index, $\mathrm{CI}=(\lambda \max -\mathrm{n}) / \mathrm{n}-1 ; \mathrm{n}=6$

$$
\begin{aligned}
& \mathrm{CI}=(6.3271-6) / 6-1=0.3271 / 5=\mathbf{0 . 0 6 5 4 2} \\
& \mathrm{CR}=\mathrm{CI} / \mathrm{RI} \text {; but } \mathrm{RI} \text { for } \mathrm{n} \text { at } 6=1.24 \text { from table } 2.2 \\
& \mathrm{CR}=0.06542 / 1.24=\mathbf{0 . 0 5 4 5 2}
\end{aligned}
$$

Similarly, for all other pairwise comparison, this process is followed and the results presented in Tables $3-11$.

Table 3 shows pairwise comparison of Criteria by allocating scores to each respective criterion compared with other criteria. 
Table 3: AHP Pairwise Comparison Matrix of the Criteria with Respect to the Goal

\begin{tabular}{lcccccccc}
\hline Criteria & Cost & Availability & $\begin{array}{c}\text { Ease of } \\
\text { distribution }\end{array}$ & Accessibility & Sustainability & Quality & $\begin{array}{c}6^{\text {th }} \text { root } \\
\text { of } \\
\text { Product }\end{array}$ & $\begin{array}{c}\text { Priority } \\
\text { Vector }\end{array}$ \\
\hline Cost & 1 & 0.143 & 0.5 & 0.25 & 0.143 & 1 & 0.3698 & 0.0476 \\
$\begin{array}{l}\text { Availability } \\
\begin{array}{l}\text { Ease of } \\
\text { distribution }\end{array}\end{array}$ & 7 & 1 & 7 & 1 & 1 & 1 & 1.9129 & 0.2462 \\
Accessibility & 4 & 0.143 & 1 & 0.25 & 0.111 & 0.5 & 0.3978 & 0.0512 \\
Sustainability & 7 & 1 & 4 & 1 & 1 & 2 & 1.7818 & 0.2293 \\
Quality & 1 & 1 & 9 & 1 & 1 & 4 & 2.5132 & 0.3235 \\
SUM & $\mathbf{2 2}$ & $\mathbf{4 . 2 8 5 7}$ & $\mathbf{2 3 . 5}$ & $\mathbf{4}$ & $\mathbf{3 . 5 0 4}$ & $\mathbf{9 . 5}$ & $\mathbf{7 . 7 6 9 2}$ & $\mathbf{1}$ \\
\hline
\end{tabular}

As presented in Table 4, a consistency ratio (CR) of 0.05452 was obtained and is acceptable because it is less than 0.1 and therefore the judgment is consistent. This means that the decisions made by the water experts in the pairwise comparison are consistent.

Table 4: Pair-wise comparison showing Consistency Index and Consistency Ratio

\begin{tabular}{|c|c|c|c|c|c|c|c|c|}
\hline Criteria & Cost & Availability & $\begin{array}{c}\text { Ease of } \\
\text { distribution }\end{array}$ & Accessibility & Sustainability & Quality & $\begin{array}{c}\text { 6th } \\
\text { root of } \\
\text { Product }\end{array}$ & $\begin{array}{c}\text { Priority } \\
\text { Vector } \\
(\mathrm{PV}) \\
\end{array}$ \\
\hline Cost & 1 & 0.143 & 0.5 & 0.25 & 0.143 & 1 & 0.3698 & 0.0476 \\
\hline Availability & 7 & 1 & 7 & 1 & 1 & 1 & 1.9129 & 0.2462 \\
\hline $\begin{array}{l}\text { Ease of } \\
\text { distribution }\end{array}$ & 2 & 0.143 & 1 & 0.25 & 0.111 & 0.5 & 0.3978 & 0.0512 \\
\hline Accessibility & 4 & 1 & 4 & 1 & 1 & 2 & 1.7818 & 0.2293 \\
\hline Sustainability & 7 & 1 & 9 & 1 & 1 & 4 & 2.5132 & 0.3235 \\
\hline Quality & 1 & 1 & 2 & 0.5 & 0.25 & 1 & 0.7937 & 0.1022 \\
\hline SUM & 22 & 4.2857 & 23.5 & 4 & 3.504 & 9.5 & 7.7692 & 1 \\
\hline SUM*PV & 1.0472 & 1.0551 & 1.2032 & 0.9172 & 1.1335 & 0.9709 & 6.3271 & \\
\hline$\lambda \max$ & 6.3271 & & & & & & & \\
\hline CI & 0.06542 & & & & & & & \\
\hline $\mathrm{CR}$ & 0.05452 & & & & & & & \\
\hline
\end{tabular}

Table 5: Ratings for each decision alternative for each criterion

\begin{tabular}{lcccccc}
\hline Alternatives & Rainfall & $\begin{array}{c}\text { Surface } \\
\text { Water }\end{array}$ & Ground Water & $\begin{array}{c}\text { Storm Water } \\
\text { runoff }\end{array}$ & $\begin{array}{c}\text { 4th root of } \\
\text { Product }\end{array}$ & $\begin{array}{c}\text { Priority Vector } \\
(\mathrm{PV})\end{array}$ \\
\hline Rainfall & 1 & 5 & 3 & 5 & 2.9428 & 0.5316 \\
Surface water & 0.2 & 1 & 0.2 & 1 & 0.4472 & 0.0808 \\
Ground Water & 0.3333 & 5 & 1 & 5 & 1.699 & 0.3069 \\
Storm Water runoff & 0.2 & 1 & 0.2 & 1 & 0.4472 & 0.0808 \\
SUM & $\mathbf{1 . 7 3 3 3}$ & $\mathbf{1 2}$ & $\mathbf{4 . 4}$ & $\mathbf{1 2}$ & $\mathbf{5 . 5 3 6 2}$ & $\mathbf{1 . 0 0 0 1}$ \\
SUM*PV & 0.9214 & 0.9696 & 1.3504 & 0.9696 & 4.2110 & \\
$\Lambda$ max & 4.2110 & & & & & \\
CI & 0.0703 & & & & & \\
CR & 0.0781 & & & & & \\
\hline
\end{tabular}




\subsection{Ratings for each Decision Alternative}

Pairwise comparison was carried out for each alternative using criteria adopted for this study. The ratings for each decision alternative are presented in Tables $6-11$.

Table 6 Ratings for Availability

\begin{tabular}{lcccccc}
\hline Alternatives & Rainfall & $\begin{array}{c}\text { Surface } \\
\text { Water }\end{array}$ & Ground Water & $\begin{array}{c}\text { Storm Water } \\
\text { runoff }\end{array}$ & $\begin{array}{c}\text { 4th root of } \\
\text { Product }\end{array}$ & $\begin{array}{c}\text { Priority Vector } \\
\text { (PV) }\end{array}$ \\
\hline Rainfall & 1 & 0.2 & 0.1429 & 1 & 0.4112 & 0.0685 \\
Surface water & 5 & 1 & 0.3333 & 5 & 1.699 & 0.2830 \\
Ground Water & 7 & 3 & 1 & 7 & 3.4820 & 0.5800 \\
Storm Water runoff & 1 & 0.2 & 0.1429 & 1 & 0.4112 & 0.0685 \\
SUM & $\mathbf{1 4}$ & $\mathbf{4 . 4}$ & $\mathbf{1 . 6 1 9 1}$ & $\mathbf{1 4}$ & $\mathbf{6 . 0 0 3 4}$ & $\mathbf{1}$ \\
SUM*PV & 0.959 & 1.2452 & 0.9391 & 0.959 & 4.1023 & \\
$\Lambda$ max & 4.1023 & & & & & \\
CI & 0.0341 & & & & & \\
CR & 0.0379 & & & & & \\
\hline
\end{tabular}

Table 7: Ratings for Ease of Distribution

\begin{tabular}{|c|c|c|c|c|c|c|}
\hline Alternatives & Rainfall & $\begin{array}{c}\text { Surface } \\
\text { Water }\end{array}$ & Ground Water & $\begin{array}{c}\text { Storm Water } \\
\text { runoff }\end{array}$ & $\begin{array}{c}\text { 4th root of } \\
\text { Product }\end{array}$ & $\begin{array}{c}\text { Priority Vector } \\
(\mathrm{PV})\end{array}$ \\
\hline Rainfall & 1 & 0.3333 & 0.3333 & 3 & 0.7598 & 0.1522 \\
\hline Surface water & 3 & 1 & 0.3333 & 2 & 1.1892 & 0.2383 \\
\hline Ground Water & 3 & 3 & 1 & 5 & 2.5900 & 0.5190 \\
\hline Storm Water runoff & 0.3333 & 0.5 & 0.25 & 1 & 0.4518 & 0.0905 \\
\hline SUM & 7.3333 & 4.8333 & 1.9166 & 11 & 4.9908 & 1 \\
\hline SUM*PV & 1.1161 & 1.1518 & 0.9947 & 0.9955 & 4.2581 & \\
\hline$\Lambda \max$ & 4.2581 & & & & & \\
\hline $\mathrm{CI}$ & 0.0860 & & & & & \\
\hline $\mathrm{CR}$ & 0.0956 & & & & & \\
\hline
\end{tabular}

Table 8: Ratings for Accessibility

\begin{tabular}{|c|c|c|c|c|c|c|}
\hline Alternatives & Rainfall & $\begin{array}{l}\text { Surface } \\
\text { Water }\end{array}$ & Ground Water & $\begin{array}{l}\text { Storm Water } \\
\text { Runoff }\end{array}$ & $\begin{array}{c}\text { 4th root of } \\
\text { Product }\end{array}$ & $\begin{array}{c}\text { Priority } \\
\text { Vector } \\
(\mathrm{PV})\end{array}$ \\
\hline Rainfall & 1 & 2 & 3 & 5 & 2.3403 & 0.4690 \\
\hline Surface water & 0.5 & 1 & 3 & 4 & 1.5651 & 0.3137 \\
\hline Ground Water & 0.3333 & 0.3333 & 1 & 2 & 0.6866 & 0.1376 \\
\hline Storm Water runoff & 0.2 & 0.25 & 0.5 & 1 & 0.3976 & 0.0797 \\
\hline SUM & 2.0333 & 3.5833 & 7.5 & 12 & 4.9896 & 1 \\
\hline SUM*PV & 0.9536 & 1.1241 & 1.032 & 0.9564 & 4.0661 & \\
\hline$\Lambda \max$ & 4.0661 & & & & & \\
\hline $\mathrm{CI}$ & 0.0220 & & & & & \\
\hline CR & 0.0244 & & & & & \\
\hline
\end{tabular}


Table 9: Ratings for Sustainability

\begin{tabular}{lcccccc}
\hline Alternatives & Rainfall & $\begin{array}{c}\text { Surface } \\
\text { Water }\end{array}$ & Ground Water & $\begin{array}{c}\text { Storm Water } \\
\text { runoff }\end{array}$ & $\begin{array}{c}\text { 4th root of } \\
\text { Product }\end{array}$ & $\begin{array}{c}\text { Priority } \\
\text { Vector } \\
(\mathrm{PV})\end{array}$ \\
\hline Rainfall & 1 & 0.2 & 0.2 & 1 & 0.447 & 0.0793 \\
Surface water & 5 & 1 & 0.5 & 5 & 1.8803 & 0.3339 \\
Ground Water & 5 & 2 & 1 & 7 & 2.8925 & 0.5137 \\
Storm Water runoff & 1 & 0.2 & 0.1429 & 1 & 0.4112 & 0.0730 \\
SUM & $\mathbf{1 2}$ & $\mathbf{3 . 4}$ & $\mathbf{1 . 8 4 2 9}$ & $\mathbf{1 4}$ & $\mathbf{5 . 6 3 1}$ & $\mathbf{0 . 9 9 9 9}$ \\
SUM*PV & 0.9516 & 1.1353 & 0.9467 & 1.022 & 4.0556 & \\
$\Lambda$ max & 4.0556 & & & & & \\
CI & 0.0185 & & & & & \\
CR & 0.0206 & & & & & \\
\hline
\end{tabular}

Table 10: Ratings for Quality

\begin{tabular}{|c|c|c|c|c|c|c|}
\hline Alternatives & Rainfall & $\begin{array}{l}\text { Surface } \\
\text { Water }\end{array}$ & $\begin{array}{l}\text { Ground } \\
\text { Water }\end{array}$ & $\begin{array}{l}\text { Storm Water } \\
\text { runoff }\end{array}$ & $\begin{array}{l}\text { 4th root of } \\
\text { Product }\end{array}$ & $\begin{array}{c}\text { Priority } \\
\text { Vector } \\
\text { (PV) }\end{array}$ \\
\hline Rainfall & 1 & 5 & 0.5 & 5 & 1.8803 & 0.3460 \\
\hline Surface water & 0.2 & 1 & 0.2 & 1 & 0.4472 & 0.0823 \\
\hline Ground Water & 2 & 5 & 1 & 5 & 2.6591 & 0.4894 \\
\hline $\begin{array}{l}\text { Storm Water } \\
\text { runoff }\end{array}$ & 0.2 & 1 & 0.2 & 1 & 0.4472 & 0.0823 \\
\hline SUM & 3.4 & 12 & 1.9 & 12 & 5.4338 & 1 \\
\hline SUM*PV & 1.1764 & 0.9876 & 0.9299 & 0.9876 & 4.0815 & \\
\hline$\lambda \max$ & 4.0815 & & & & & \\
\hline $\mathrm{CI}$ & 0.0272 & & & & & \\
\hline $\mathrm{CR}$ & 0.0302 & & & & & \\
\hline
\end{tabular}

Table 11: Weighted Average Rating

\begin{tabular}{|c|c|c|c|c|c|c|c|}
\hline Clternative & Cost & Availability & Ease of distribution & Accessibility & Sustainability & Quality & Score \\
\hline & 0.0476 & 0.2462 & 0.0512 & 0.2293 & 0.3235 & 0.1022 & 1 \\
\hline Rainfall & 0.5316 & 0.0685 & 0.1522 & 0.4690 & 0.0793 & 0.3460 & $\mathbf{0 . 2 1 8 6}$ \\
\hline Surface water & 0.0808 & 0.2830 & 0.2383 & 0.3137 & 0.3339 & 0.0823 & $\mathbf{0 . 2 7 4 0}$ \\
\hline Ground water & 0.3069 & 0.5800 & 0.5190 & 0.1376 & 0.5137 & 0.4894 & $\mathbf{0 . 4 1 3 0}$ \\
\hline Storm runoff & 0.0808 & 0.0685 & 0.0905 & 0.0797 & 0.0730 & 0.0823 & $\mathbf{0 . 0 7 5 6}$ \\
\hline & 1.0001 & 1 & 1 & 1 & 0.9999 & 1 & \\
\hline
\end{tabular}

Table 11 shows that ground water has the highest score. Hence, ground water is chosen as the best alternative.

\subsection{Conclusion}

Decision-making is a complex process that requires a comprehensive evaluation of the criteria bothering the problem being assessed. The AHP has been widely accepted as a convenient decision-making tool, and this reflects in its wide use in academia and in the business community.

In this study, the AHP methodology was employed to select the best water supply source for Benin City.

The criteria considered in making the decision included Cost, Availability, Ease of distribution, Accessibility, Sustainability and Quality while the alternatives considered were Rainfall, Ground Water, Surface Water and Storm Water Runoff. In analysing the pairwise comparative judgments in this study, 
Cost was found to be the most important criteria and Ground Water, the most important alternative as it had the highest score in the computation of the weighted average.

Despite the strengths of the AHP, it comes with some observed weaknesses. The problem of inconsistency in the judgment was observed. This often resulted in situations where we had to reevaluate our responses to questions raised in order to satisfy the acceptable inconsistency limit.

\section{References}

Alireza A. (2014) 2Application of AHP model in selection of appropriate area to establish soil damp for artificial recharge of underground aquifers". Global journal of human-social science: B Geography, geoscience, environmental and disaster management. Volume 14 issue 8, page $54-63$.

Ariff, H., Salit, M. S., Ismail, N. \& Nukman, Y. (2008) "Use of Analytical Hierarchy Process (AHP) for selecting the best design concept". Jurnal Teknologi, 49(A) Dis, 1-18.

Kasperczyk, N. \& Knickel, K. (2006). "The Analytic Hierarchy Process (AHP)". Available at: www.ivm.vu.nl/en/Images/MCA3_tcm53-161529.pdf

Moore \& Weatherford (2001) "Decision Modelling with Microsoft Excel" 6th edition. pp 12-26.

Render \& Stair (2000) "Quantitative Analysis for management" 7th Edition Pp522-529

Saaty T.L. (1980), "The Analytic Hierarchy Process". McGraw-Hill: New York

Saaty T.L. (1995). "Decision Making for Leaders: The Analytical Hierarchy Process for Decisions in complex World" RWS Publications, Pittsburgh

Saaty T.L. (2005) "The Analytic Hierarchy and Analytic Network Process for the measurement of intangible criteria and for decision making". In: Figueira J, Salvatore G, Ehrgott M (eds) "Multiple Criteria Decision Analysis: state of the art surveys". Springer, Berlin Heidelberg New York, pp345-407

United Nations (2006) "Millennium Development Goal Report” United Nations, New York. 